\title{
Estimation of Genetic Variability, Heritability and Genetic Advance in Bread Wheat (Triticum aestivum L.)
}

\author{
Endashaw Girma Seyoum ${ }^{1 *}$, Alemnesh Sisay ${ }^{2}$ \\ Wheat Breeder Crop Research Program Ethiopian Institute of Agriculture Research Holetta Research Center, \\ Addis Ababa, Ethiopia, \\ Natural resource management research Program Ethiopian Institute of Agriculture Research Holetta Research \\ Center,. Addis Ababa, Ethiopia,
}

*Corresponding Authors: Endashaw Girma Seyoum, Wheat Breeder Crop Research Program Ethiopian Institute of Agriculture Research Holetta Research Center, Addis Ababa, Ethiopia

\begin{abstract}
Wheat (Triticum aestivum L.) is high yielder and wider adaptability of the staple food for a large part of the world population including Ethiopia. Although the productivity of wheat has increased in the last few years in Ethiopia, it is still very low as compared to other wheat producing countries mainly due to biotic and abiotic factors. Therefore, in this study conducted on genetic variability in grain yield and yield related characters of 49 bread wheat genotypes. An experiment was undertaken at two locations viz; Holetta and Kulumsa Agricultural research center in Ethiopia in 2016/17 cropping season. The materials were evaluated in the simple lattice design with two replications. Data on yield and yield component were collected and analyzed using SAS version 9.3 software. Results revealed that very high estimates of heritability across locations were obtained in the case of days to heading (95.66\%), plant height (90.74\%) and grain filling period (85.21\%). High heritability coupled with moderate genetic advance as a percent of means were noted for days to heading, Plant height, grain filling period and spike length. So, it concluded that this trait may be considered as the selection criteria for the improvement of grain yield. However, further study needs to be conducted the future bread wheat breeding effort should be focus on varietal development.
\end{abstract}

Keywords: Bread wheat, Broad sense heritability, Genetic advance, Grain yield

\section{INTRODUCTION}

World wheat production is based almost completely on two modern species: hexaploid bread wheat (Triticum aestivum $L, 2 n=6 X=42, A A B B D D$ ) and tetraploid wheat (T. turgidum subsp. durum, $2 n=$ $4 X=28, A A B B$ (Sears, 1966). Wheat can grow in the Ethiopian highlands, which are located between $6^{\circ}$ and $16^{\circ} \mathrm{N}$, latitude and $35^{\circ}$ and $42^{\circ} \mathrm{E}$, longitude at altitude ranging from 1500 - 3000 m.a.s.l. However, the most appropriate altitude zones of wheat fall between 1900 - 2700 m.a.s.l (Bekele et al., 2000). Dissimilar rice and maize, which prefer to tropical environment, wheat is extensively grown in temperate regions occupying $17 \%$ of all crop acreage worldwide. Currently it is also attractive most important cereals grown on a large scale (Fasil et al., 2000), because of its significance as cash crop, high level of production per unit area, its major role in providing the nutritional requirements of the society.

Wheat is one of the major staple and strategic food security crops in Ethiopia (Letta, 2013; Bezabeh et al., 2015) cultivated by half a million house holders on about 1.7 million ha. In spite of its incredible contributions to food and nutritional security of the country, the national average wheat productivity is $2.37 \mathrm{t} /$ ha far below the global average of $3.27 \mathrm{t} / \mathrm{ha}$ (FAOSTAT, 2018).

A gap in the yield was attributed mainly due to shortage of improved varieties for different agro ecological zones of the country. In addition, poor agronomic practices, drought, poor soil fertility, diseases and insect pests, etc. are the major constraints of wheat production in Ethiopia (Fikire et al., 2015). Hence, it is necessary to generate information on phenotypic and genotypic variances as well as heritability and genetic advance among bread wheat varieties as one of the approaches to alleviate these limitations.

The success of a breeding program depends largely upon the amount of genetic variability present in the population and the extent to which the desired traits are heritable (Majumder et al., 2008). 
Heritability is an indicator for transfer of traits of interest from parents to its progeny and is widely used in breeding programs (Falconer, 1981).

The genetic advance (GA) is another important parameter to selection (Shukla et al., 2004) Phenotypic and genotypic coefficients of variations, heritability and genetic advance have been widely used in wheat to assess the magnitude of variance in breeding material, to determine appropriate selection procedures and to predict the breeding advance in improvement of important traits (Zecevic, 2001; Shukla et al., 2004, Clarke et al., 2010).

High genetic advancement together with high heritability estimates offers the most suitable condition for selection (Johnson et al., 1955). The presence of variability, heritability and genetic advance in different yield related characters of bread wheat has been reported by different authors (Obsa et al., 2017; Dabi et al., 2019; Zerga et al., 2016; Awale et al., 2013 and Gezahegn et al., 2015). More importantly changes in genetic variability such as grain yield and related traits of bread wheat were studied not incorporated the recent one including candidates. Therefore, the objective of the present study was accomplished with to estimate genotypic and phenotypic variability in bread wheat genotypes and estimate the heritability and genetic advance under selection.

\section{Materials AND Methods}

Table1. Description of the experimental sites in terms of geographical position

\begin{tabular}{|l|l|l|}
\hline \multirow{2}{*}{ Description } & Location & \multicolumn{2}{|l|}{} \\
\cline { 2 - 3 } & Holetta & Kulumsa \\
\hline Latitude & $09^{\circ} 04^{\prime} \mathrm{N}$ & $08^{\circ} 01^{\prime} \mathrm{N}$ \\
\hline Longitude & $38^{\circ} 29^{\prime} \mathrm{E}$ & $39^{\circ} 09^{\prime} \mathrm{E}$ \\
\hline Altitude(m.a.s.l.) & 2400 & 2200 \\
\hline Mean annual rainfall $(\mathrm{mm})$ & 1102 & 832 \\
\hline Mean annual temperature $\left({ }^{\circ} \mathrm{c}\right)$ & 14.23 & 16.68 \\
\hline Soil type & Nitosols & Luvisols \\
\hline
\end{tabular}

Source: Tamene. et al. (2015).

\section{Planting Materials}

The experiment was conducted to examine the genetic variability, heritability and genetic advance percent of mean for thirteen yield contributing traits in bread wheat. The experiment was evaluated on station of Holetta and Kulumsa Agricultural Research Center 2016-17 cropping season. The experimental materials consist of Fourty nine genotypes of bread wheat namely., Lakech, Enkoy, Dereselegn, K6290-Bulk, K6295-4A, Et-13 A2, Pavone-76, Batu, Dashen, Mitike, Kubsa, Galama, Tusi, Katar, Wetera, Hawi, Meda - Welabu, Sofumer, Sirbo, Doddota, KBG01, Bobicho, Digelu, Tay, Mararo, Alidoro, Millinium, Gassay, Danda'a, Kakaba, Hoggena, Shorima, Huluka, Ogolcho, Jefferson, Hidasse, Honqolo, Biqa, Mandoye, Sanate, Kingbird, Liben, Buluk, Dembel, Lemu, Wane,,ETBW8506, ETBW 8491and ETBW 9027. Those materials were grown in simple lattice incomplete block design; the arrangements

Of $(7 * 7)$ with two replications. The plot size was six rows of $2.5 \mathrm{~m}$ length with $0.2 \mathrm{~m}$ row spacing $\left(1.2 \mathrm{~m} * 2.5 \mathrm{~m}=3 \mathrm{~m}^{2}\right)$. The spacing was between plots $(0.4 \mathrm{~m})$, block $(0.5 \mathrm{~m})$ and replications $(1.5 \mathrm{~m})$. The rate of seed was $150 \mathrm{~kg} \mathrm{ha}^{-1}(45 \mathrm{~g} / \mathrm{plot})$ with recommended fertilizer rate of 60:69 $\mathrm{N}_{2}: \mathrm{P}_{2} \mathrm{O}_{5}$ per hectare. All other crop management practices were applied uniformly to all plots as required.

Data on agro morphological traits of wheat varieties were collected on plot and plant basis on the following characters viz., Days to (heading and maturity), Grain Filling Period, Thousand Kernel Weight, Hectoliter Weight, Grain Yield, Biomass Yield, Harvest Index, Plant Height, Spike Length, Number of Kernels per Spike, and Number of spikelets per spike. The analysis of variances heritability in broad sense (H2Bs) is suggested by Hanson (1956) and genetic advance (GA) was estimated by Johnson (1956).

\section{Statistical Analysis}

The data were subjected to analysis of variance (ANOVA), according to general linear model using SAS 9.3 (SAS Institute, 2012) and Microsoft Excel (2010). Data of mean values of all experimental units were subjected to analysis of variance (ANOVA) based on (Table 2).For pooled analysis of 
variance over location was conducted to measure the total variation among the varieties using the following model:

$P_{i j k z}=\mu+g_{i}+b_{k}(j)(z)+r_{j}(z)+l_{z}+(g l)+e_{i j k z}$

Where, Pijkz $=$ phenotypic value of $\mathrm{i}^{\text {th }}$ genotype under $\mathrm{j}^{\text {th }}$ replication at $\mathrm{z}^{\text {th }}$ location and $\mathrm{k}^{\text {th }}$ incomplete block within replication $j$ and location $z ; \mu=$ grand mean; gi $=$ the effect of $i^{\text {th }}$ genotype; $b k(j)(z)=$ the effect of incomplete block $\mathrm{k}$ within replication $\mathrm{j}$ and location $\mathrm{z} ; \mathrm{rj}(\mathrm{z})=$ the effect of replication $\mathrm{j}$ within location $\mathrm{z} ; \mathrm{lz}=$ the effect of location $\mathrm{z} ;(\mathrm{gl})$ is $=$ the interaction effects between genotype and location; and eijkz $=$ the residual or effect of random error.

Table1. Analysis of variance model combined over location

\begin{tabular}{|l|l|l|l|}
\hline Source of variation & Degree freedom & $\begin{array}{l}\text { Mean square } \\
(\mathrm{MS})\end{array}$ & $\begin{array}{l}\text { Expected mean square } \\
(\mathrm{EMS})\end{array}$ \\
\hline Location (L) & $\mathrm{L}-1$ & MSL & $\sigma^{2} \mathrm{e}+\mathrm{r} \sigma^{2} \mathrm{gi}+\mathrm{g} \sigma^{2} \mathrm{~L}$ \\
\hline Replication(r) & $\mathrm{r}-1$ & MSR & $\sigma^{2} \mathrm{e}+\mathrm{g} \sigma^{2} \mathrm{r}$ \\
\hline Blocks within replication(b) & $\mathrm{r}(\mathrm{b}-1)$ & MSB & $\sigma^{2} \mathrm{e}+\mathrm{r} \sigma^{2} \mathrm{gi}+\mathrm{r} \sigma^{2} \mathrm{~g}$ \\
\hline Genotypes (g) & $\mathrm{g}-1$ & MSG & $\sigma \mathrm{e} 2+\mathrm{r} \sigma^{2} \mathrm{gi}+\mathrm{rL} \sigma^{2} \mathrm{~g}$ \\
\hline g x L interaction (i) & (g-1)(L-1) & MSGL & $\sigma^{2} \mathrm{e}+\mathrm{r} \sigma^{2} \mathrm{gi}$ \\
\hline Error (e) & $\mathrm{Lg}(\mathrm{r}-1)-(\mathrm{rb}-1)$ & MSE & $\sigma^{2} \mathrm{e}$ \\
\hline
\end{tabular}

Where, $\mathrm{b}$ represent blocks; $\delta^{2} \mathrm{~g}=$ genotypic variance, $\sigma^{2} \mathrm{e}=$ environmental variance, $\sigma^{2} \mathrm{~L}=$ location variance, $\sigma^{2} \mathrm{r}=$ replication variance, and $\sigma^{2}$ gi $=$ genotype $\mathrm{x}$ location interaction variance, $\mathrm{L}=$ number of locations, $\mathrm{g}=$ number of genotypes and $\mathrm{r}=$ number of replications.

For combined analysis of variance over location, the homogeneity of error variance was tested using $\mathrm{F}$ - max test method of Hartley (1950), which is based on the ratio of the larger mean square of error (MSE) from the separate analysis of variance to the smaller mean square of error variance given by the following formula: $\mathrm{F}$ - Max $=\frac{\text { Largest } M S E}{\text { Smallest } M S E}$

If the calculated value of F-max was less than three, it means that the ratio of the highest error mean square is not three fold larger than the smallest error mean square, and this indicates that the variance was considered homogenous thereby making it to possible to proceed with the combine analysis of variance (Gomez and Gomez, 1984). Then pooled analysis of variance over locations was done using SAS Statistical package (SAS Institute, 2012). Mean separation was carried out using Least Significant Difference (LSD) at $5 \%$ of significance.

\section{Estimation of Genetic Parameters}

The genotypic, phenotypic and environmental variance component and coefficient of phenotypic (PCV $\%)$ and genotypic coefficient of variation ( $\mathrm{GCV} \%$ ) were estimated based on the method suggested by Burton and devane (1953).

Genotypic variance $=\frac{M s g-M s g l}{r l}$

Environmental variance $\left(\delta^{2} \mathrm{e}\right)=$ error mean square

Phenotypic variance $\left(\sigma^{2} \mathrm{p}=\delta^{2} \mathrm{~g}+\delta^{2} \mathrm{e}+\delta^{2} \mathrm{gl}\right)$ combined over location

$\sigma_{\mathrm{p}=}^{2} \delta_{\mathrm{g}}^{2}+\frac{\sigma 2 \mathrm{gL}}{L}+\frac{\sigma 2 \mathrm{e}}{r L}$, where $\sigma^{2} \mathrm{gl}=\frac{M S g l-M S e}{r}$

Where $\sigma^{2} \mathrm{gl}=$ variance of genotype by location interaction

$\mathrm{MSe}=$ error mean square; $\mathrm{MSgl}=$ genotype by location interaction mean square

$\mathrm{MSg}=$ genotype mean square; $\mathrm{r}=$ replication; 1 = location

Phenotypic coefficient of variation (PCV \%), PCV $=\frac{\sqrt{\delta^{2} \mathbf{p}}}{\overline{\mathbf{x}}} \times 100$

Genotypic coefficient of variation (GCV \%), GCA $=\frac{\sqrt{\delta^{2} g}}{\overline{\mathbf{x}}} \times 100$ 


\section{Broad-Sense Heritability $\left(\mathrm{H}^{2} \mathrm{~B}\right)$}

Broad sense heritability on plot and plant basis was computed for all traits based on the formula given by Falconer and Mackay (1996).

Heritability $\left(\mathrm{H}^{2} \mathrm{~B}\right)=\frac{\sigma 2 \mathrm{~g}}{\sigma 2 \mathrm{p}} \times 100, \mathrm{~h} 2=\frac{\sigma 2 \mathrm{~g}}{\delta 2 \mathrm{~g}+\frac{\sigma 2 \mathrm{gL}}{L}+\frac{\sigma_{2 \mathrm{e}}}{r L}} \times 100$, for combined locations

Where: $\mathrm{H}=$ Heritability in Broad sense; $\delta^{2} \mathrm{p}=$ Phenotypic variance; $\delta^{2} \mathrm{~g}=$ Genotypic variance

\section{Genetic advance under selection (GA)}

The expected genetic advance for each trait at selection intensity of $5 \%$ was computed using methodology given by Allard (1960).

$\mathrm{GA}=\mathrm{K} \cdot \mathrm{h}^{2} \mathrm{~b} . \sigma \mathrm{p}$;

Where: $\mathrm{GA}=$ Expected genetic advance; $\mathrm{k}=$ the standardized selection differential at $5 \%$ selection intensity $(\mathrm{K}=2.063)$; $\sigma \mathrm{p}=$ Phenotypic standard deviation; $\mathrm{H}=$ Heritability in broad sense

\section{Genetic advance as percent of mean}

Genetic advance as percent of mean was calculated to compare the amount of predicted advance of different traits under selection, using the following formula:

$\mathrm{GAM}=\frac{\mathrm{GA}}{\overline{\mathrm{x}}} \times 100$

Where: $\mathrm{GAM}=$ Genetic advance as percent of mean; $\mathrm{GA}=$ Genetic advance under selection; $\overline{\mathrm{x}}=\mathrm{Grand}$ Mean of the population

\section{RESULTS AND DISCUSSION}

\section{Analysis of Variance}

Prior to performing analysis of variance, tests were made to confirm the homogeneity of error variances. The two locations showed homogeneity of error variances. Consequently, the data were pooled across locations and analyzed. The results of the combined analysis of variance across the two locations are presented on (Table 2).

The combined analysis of variance over two locations presented (Table 2) mean squares of genotypes were significant $(\mathrm{P} \leq 0.01)$ for all characters including days to heading, days to maturity, plant height, grain filling period, thousand kernel weight. Hector liter weight, spike length, number of spike let per spike .number of grain per spike, biomass yield, harvest index and grain yield except number of tiller. The significant of those traits indicated that the existence of enormous amount of genetic variability for growth and yield attributes. Hence, selection could be effective to different quantitative characters including crossing program as well as creating variability. Similar findings were also reported by Navi et al. (2014); Dabi et al. (2019).

The location* genotypes interaction for thirteen characters of Fourty nine genotypes presented (Table 2) highly significant for all the characters except biomass yield, number of tillers, spike length and number of spikelet per spike. This implies that the not performed consistently over locations with regard to this traits. On the other hand reveal variety selected for those traits at one location may not exhibit a similar relative performance at another location. If varieties not perform consistently for those traits over locations, breeders may be able to extensive varietal evaluation by appropriate testing sites and by modifying the breeding programs. To effectively assess varietal performance for significant traits, it's essential to consider wide location interaction and identify trait performance in relations to location effect. Similar findings were also reported on bead wheat by Dabi et al. (2019) for most of the traits studied.

Table2. Combined analysis of variance over locations for grain yield and yield related character of bread wheat varieties grown in the yield potential trials at Kulumsa and Holetta. 


\begin{tabular}{|c|c|c|c|c|c|c|c|c|c|c|}
\hline & MSL (1) & $\begin{array}{l}\text { MSG } \\
(48)\end{array}$ & $\begin{array}{l}\text { MSLG } \\
(48)\end{array}$ & $\begin{array}{l}\text { Group } \\
\text { (Loc.) (1) }\end{array}$ & $\begin{array}{l}\text { Block } \\
\text { (Group) } \\
\text { (12) }\end{array}$ & $\begin{array}{l}\text { MSE } \\
\text { (85) }\end{array}$ & Mean & $\begin{array}{l}\text { CV } \\
(\%)\end{array}$ & $\mathbf{R 2}$ & $\begin{array}{l}\text { LSD } \\
(5 \% \\
\end{array}$ \\
\hline$\overline{\mathrm{DH}}$ & $75.94 * *$ & $133.06^{* *}$ & $5.77 * *$ & $0.33 \mathrm{~ns}$ & $2.52 \mathrm{~ns}$ & 1.34 & 66.58 & 1.74 & $\begin{array}{l}0.9 \\
9\end{array}$ & 1.62 \\
\hline $\mathrm{DM}$ & $32015.43 * *$ & $57.33^{* *}$ & $12.08^{* *}$ & $4.90 \mathrm{~ns}$ & $10.19 *$ & 5.19 & $\begin{array}{l}133.6 \\
2\end{array}$ & 1.70 & $\begin{array}{l}0.9 \\
9\end{array}$ & 3.2 \\
\hline $\mathrm{PH}$ & $1929.72 * *$ & $246.86^{* *}$ & $22.85^{* *}$ & 36.86ns & $18.14 \mathrm{~ns}$ & 12.46 & 99.19 & 3.56 & $\begin{array}{l}0.9 \\
5\end{array}$ & 4.96 \\
\hline $\begin{array}{l}\text { GF } \\
P\end{array}$ & $28972.90 * *$ & $70.78^{* *}$ & $10.47 * *$ & $2.69 \mathrm{~ns}$ & $5.39 \mathrm{~ns}$ & 5.39 & 67.04 & 3.47 & $\begin{array}{l}0.9 \\
9\end{array}$ & 3.27 \\
\hline $\begin{array}{l}\text { TK } \\
W\end{array}$ & $305.001 * *$ & $46.79^{* *}$ & $21.002 * *$ & $10.28 \mathrm{~ns}$ & $10.53^{*}$ & 5.12 & 36.06 & 6.27 & $\begin{array}{l}0.9 \\
1\end{array}$ & 3.18 \\
\hline $\begin{array}{l}\text { HL } \\
W\end{array}$ & $2486.52 * *$ & $12.70^{* *}$ & $5.54 * *$ & $5.92 *$ & $1.29 \mathrm{~ns}$ & 1.08 & 76.18 & 1.36 & $\begin{array}{l}0.9 \\
7\end{array}$ & 1.46 \\
\hline $\begin{array}{l}\text { BM } \\
\text { Y }\end{array}$ & $\begin{array}{l}7427703.9 * \\
*\end{array}$ & $\begin{array}{l}2202267 . \\
8^{* * *}\end{array}$ & $\begin{array}{l}1060555 . \\
4 \mathrm{~ns}\end{array}$ & $\begin{array}{l}2215130 . \\
4 n s\end{array}$ & $\begin{array}{l}1893042 . \\
9 * *\end{array}$ & $\begin{array}{l}76331 \\
4.7\end{array}$ & $\begin{array}{l}7543 . \\
3\end{array}$ & $\begin{array}{l}11.5 \\
8\end{array}$ & $\begin{array}{l}0.7 \\
8\end{array}$ & $\begin{array}{l}1228 \\
.5\end{array}$ \\
\hline $\mathrm{HI}$ & $1800.002 * *$ & $186.53^{* *}$ & $99.43 * *$ & $281.11^{*}$ & $65.16 \mathrm{~ns}$ & 47.86 & 45.66 & $\begin{array}{l}15.1 \\
5\end{array}$ & $\begin{array}{l}0.8 \\
3\end{array}$ & 9.73 \\
\hline NT & $128.98 * *$ & $128.98 \mathrm{~ns}$ & $1.96 \mathrm{~ns}$ & $1.47 \mathrm{~ns}$ & $4.31^{*}$ & 2.001 & 5.49 & $\begin{array}{l}25.7 \\
4\end{array}$ & $\begin{array}{l}0.7 \\
0\end{array}$ & 1.99 \\
\hline SL & $6.76 * *$ & $1.89^{* *}$ & $0.42 \mathrm{~ns}$ & $0.02 \mathrm{~ns}$ & $0.36 \mathrm{~ns}$ & 0.47 & 8.11 & 8.46 & $\begin{array}{l}0.7 \\
6\end{array}$ & 0.97 \\
\hline $\begin{array}{l}\text { NS } \\
\text { S }\end{array}$ & $218.62 * *$ & $6.02^{* *}$ & $2.09 \mathrm{~ns}$ & $8.58^{*}$ & $1.80 \mathrm{~ns}$ & 1.62 & 19.41 & 6.56 & $\begin{array}{l}0.8 \\
4\end{array}$ & 1.79 \\
\hline $\begin{array}{l}\text { NG } \\
\text { S }\end{array}$ & $5476.00 * *$ & $56.82^{* *}$ & $39.99 * *$ & $39.51 \mathrm{~ns}$ & $14.25 \mathrm{~ns}$ & 14.99 & 51.81 & 7.47 & $\begin{array}{l}0.8 \\
9\end{array}$ & 5.44 \\
\hline GlY & $\begin{array}{l}14571953.8 \\
0^{* *}\end{array}$ & $\begin{array}{l}950202.1 \\
4^{* * *}\end{array}$ & $\begin{array}{l}891217.9 \\
3^{* *}\end{array}$ & $\begin{array}{l}298039.5 \\
6 \mathrm{~ns}\end{array}$ & $\begin{array}{l}146700.0 \\
6 \mathrm{~ns}\end{array}$ & $\begin{array}{l}16403 \\
1.2 \\
\end{array}$ & $\begin{array}{l}3534 . \\
33\end{array}$ & $\begin{array}{l}11.4 \\
6 \\
\end{array}$ & $\begin{array}{l}0.9 \\
0 \\
\end{array}$ & $\begin{array}{l}569 . \\
51\end{array}$ \\
\hline
\end{tabular}

$*$,** Significant at $\mathrm{p} \leq 0.05$, and $\mathrm{p} \leq 0.01$ probability level respectively and $\mathrm{ns}=$ non-significant, $($ ) parenthesis indicate degrees of freedom. MSL= Mean Squares of locations, MSG= Mean squares of genotypes, MSLG = Mean square of genotype $\mathrm{x}$ location interaction, $\mathrm{MSE}=$ Mean squares of error, $\mathrm{CV}$ = Coefficient of variation. Abbreviations: $D H=$ Days to heading, $\mathrm{DM}=$ Days to maturity, $\mathrm{PH}=\mathrm{Plant}$ Height, GFP = Grain Filling Period, TKW $=$ Thousand Kernels Weight , HLW= Hectoliter weight , BMY = Biomass Yield , HI = Harvest Index , NT= Number of Tiller/plant , SL = Spike Length , NSS = Number of spikelet per spike, NGS = Number of Kernels per Spike, GlY= Grain yield $(\mathrm{Kg} / \mathrm{ha})$.

\section{Range and Mean value}

The mean values for days to $50 \%$ heading ranged from 53 (Dereselegn) to 80 days (Dashen), days to $75 \%$ maturity ranged from 126 (Dereselegn) to 143 days (Buluk). Thousand kernel weight was ranged from 26 (Lakech) to $45 \mathrm{~g} / \mathrm{plot}$ (Hidasse) and grain yield per hectare showed a wide variation which ranged from 2245 (Lakech) to $4592 \mathrm{~kg} / \mathrm{ha}$ (Dashen). Biomass yield ranged from 5641 (KBG-01) to $9588 \mathrm{~kg} / \mathrm{ha}$ (Mandoye) with a mean value of $7543.3 \mathrm{~kg} \mathrm{ha}^{-1}$ and harvest index ranged from 25 (ET-13 A2) to $61 \%$ (KBG-01) with a mean value of 45.66 . Hectoliter weight varied from 72 (Lakech) to 80 $\mathrm{kg} / \mathrm{hl}$ (Digelu), plant height ranged from 80 (Mandoye) to $119 \mathrm{~cm}$ (K6295-4A), grain filling period varied from 58 (Galama) to 78 days (Meda-Welabu) and spike length ranged from 7 (Digelu) to $10 \mathrm{~cm}$ (Alidoro). Similarly, the mean values for number of spikelets per spike and number of grains per plant were ranged from 17 (Mandoye) to 23 number (Alidoro) and 44 (Enkoy) to 64 number (ETBW 9027) respectively are presented (Table 2). Therefore, high variability for thirteen traits of Fourty nine bread wheat genotypes implied that there was reasonably sufficient variability which provides ample scope for selecting superior and desired genotypes by plant breeders for further improvement. Generally, the range of variation was wide for all the characters studied. Gezahegn et al. (2015) reported similar results on bread wheat study.

\section{Estimates of Variance Components}

Genotypic and phenotypic variance, genotypic and phenotypic coefficient of variability, broad sense heritability and genetic advance expressed as percentage of mean for thirteen characters are presented in Table 3. 


\section{Estimates of genotypic and phenotypic coefficients of variation}

According to Deshmukh (1986), the result of Phenotypic and genotypic coefficient of variation exhibited that harvest index showed wide range and moderate PCV and GCV whereas, grain yield showed moderate PCV. Similar findings were reported by earlier researchers for harvest index (Dabi et al., 2019, Bayisa et al., 2020; Mecha et al., 2016; Muhder et al., 2020). Similar findings were reported by earlier researchers for grain yield (Destaw et al., 2020).

The remaining traits recorded low GCV and PCV estimate are presented (Table 3). Through this studied, revealed low GCV and PCV reported by earlier researchers for days to heading (Bayisa et al., 2020; Meles et al., 2017; Ullah et al., 2011), days to maturity (Bayisa et al., 2020; Meles et al., 2017; Mecha et al.,2016; Ullah et al., 2011), plant height (Meles et al., 2017; Bayisa et al., 2020; Ullah et al., 2011; Bharat et al.,2013),spike length (Meles et al., 2017; Mecha et al.,2016; Bayisa et al., 2020; Ullah et al., 2011) and hectoliter weight (Bayisa et al., 2020;Meles et al., 2017; Mecha et al.,2016).

In general, the studied traits, for days to heading and maturity, gain filling period, plant height and hectoliter weight revealed that phenotypic coefficient of variation slightly higher than genotypic coefficient of variations, those traits indicated that less influenced by environment. While, for grain yield, harvest index, number of grain spike ${ }^{-1}$, biomass yield, thousand kernel weight, number of spikelet spike $^{-1}$ and spike length were showed that higher phenotypic coefficient of variation than genotypic coefficient of variations.

\section{Estimation of broad sense heritability and genetic advance}

According to Singh (2001) that heritability values greater than $80 \%$ were very high, values from $60-$ $79 \%$ were moderately high, values from $40-59 \%$ were medium and values less than $40 \%$ were low. Accordingly, very high broad sense heritability estimates were revealed for days to heading $(95.66 \%)$, plant height $(90.74 \%)$ and grain filling period $(85.21 \%)$, while high heritability values were obtained for days to maturity $(78.93 \%)$, spike length $(77.78 \%)$, and number of spikelet per spike $(65.28 \%)$. Moderate values of broad sene heritability were showed for traits namely; thousand kernel weights $(55.11 \%)$, hectoliter weight $(56.38 \%)$, harvest index (46.69\%) and biomass grain yield (51.84\%). Low values of broad sense heritability were revealed; number of grain per spike $(29.62 \%)$ and grain yield $(6.21 \%)$.

Very high estimates of broad sense heritability have been also reported by previous researchers for days to heading, plant height (Negasa et al., 2016; Kefale and Menzir, 2019; Bayisa et al., 2020); for grain filling period (Bayisa et al., 2020). Low estimates of broad sense heritability have been also reported by previous researchers for number of kernel per spike, grain yield (Adhiena et al., 2016).

Heritability values are helpful in predicting the expected progress to be achieved through selection process. Traits with high broad sense heritability estimates might respond effective to selection since it expected that, environment expression on phenotypic expression is low. Thus indicates higher relative magnitude of genotypic variance for the total variations among the studied genotypes with respective high heritability traits. Therefore, based on their phenotypic expression selection on high and very high broad sense heritability may be respond effective because it is expected that traits with high heritability estimate have a close correlation between phenotypic and genotypic appearance.

Heritability alone provides no indication of the amount of genetic improvement that would result from selection of individual genotype. Hence, knowledge on heritability coupled with genetic advance is more useful. Genetic advance (GA) under selection referred to the improvement of characters in genotypic value for the new population compared with the base population for one cycle of selection at given selection intensity (Singh, 2001). Furthermore, Hamdi et al. (2003) stated that Genetic advance (GA) is importance to predicting the expected genetic gain from one cycle of selection. Estimates of GA values for all characters studied are displayed in (Table 3).

Genetic advance as percent of the means (GAM) in this study ranged from 1.77 to $17.10 \%$ for grain yield $\mathrm{kg} / \mathrm{ha}$ and days to heading respectively (Table 3). According to Johnson et al. (1955) that the value of genetic advance as percent of the mean is categorized as low $(<10 \%)$, moderate $(10-20 \%)$ and high $(>20 \%)$. The estimates of genetic advance as percentage of the mean were moderate for days to heading (17.10\%), plant height (14.83\%), and grain filling period (11.03\%), thousand kernel weight $(10.78 \%)$, biomass grain yield $(10.52 \%)$, spike length $(13.60 \%)$ and harvest index $(14.41 \%)$. However, the 
estimates of genetic advance as percentage was low for days to maturity $(4.61 \%)$, hectoliter weight $(2.72 \%)$, number of spikelet per spike $(8.51 \%)$, number of grain per spike $(4.45 \%)$ and grain yield (1.77). Similar results have been reported for spike length by (Ghallab et al., 2016).

The traits having high values of heritability coupled with moderate genetic advance as percent of the mean namely; days to heading, plant height, grain filling period, and spike length suggest that selection for improvement of these characters may be satisfying. It also indicates greater role of non-additive gene action in their inheritance.

Similar agreement with also reported by previous researchers for plant height Dargicho et al. (2015), for days to heading, grain filling period and spike length (Obsa et al., 2017). Low heritability with low genetic advance as percent of the mean revealed for number of grain per spike and grain yield. The expression of economically importance characters through additive gene action make selection for crop improvement might be rewarding and can be confirmed by recording high value of broad sene heritability along with high genetic advance as percentage of mean (Raia et al., 2016).

Low heritability together with low genetic advance as percent of the mean for number of grain per spike and grain yield the major effect of non-additive gene action on their expression, so the genetic potential of such traits would be exploited through heterosis breeding followed by recurrent selection. The presence of higher environmental factors along with non-additive gene action might be the possible causes for the lower values of heritability and genetic advance as percentage of the mean. In line with Khalil et al. (2010) findings for number of grain per spike.

Table3. Estimation of ranges, mean, standard error (SE), variance, and coefficient of variation, heritability, genetic advance and genetic advance as \% of mean for different quantitative traits in bread wheat varieties.

\begin{tabular}{|l|l|l|l|l|l|l|l|l|l|l|}
\hline Traits & \multicolumn{1}{|l|}{$\begin{array}{l}\overline{\mathbf{x}} \\
\pm \mathrm{SE}\end{array}$} & \multicolumn{2}{l|}{ Range } & $\delta^{2} \mathrm{~g}$ & $\delta^{2} \mathrm{p}$ & $\begin{array}{l}\text { GCV } \\
(\%)\end{array}$ & $\begin{array}{l}\text { PCV } \\
(\%)\end{array}$ & $\begin{array}{l}\mathrm{H}^{2} \\
(\%)\end{array}$ & GA & $\begin{array}{l}\text { GA } \\
(\%)\end{array}$ \\
\hline DH & $\begin{array}{l}66.58 \\
\pm 0.82\end{array}$ & 52.50 & 79.50 & 31.82 & 33.27 & 8.47 & 8.66 & 95.66 & 11.38 & 17.10 \\
\hline DM & $\begin{array}{l}133.62 \\
\pm 1.61\end{array}$ & 126.25 & 143.00 & 11.31 & 14.33 & 2.52 & 2.83 & 78.93 & 6.16 & 4.61 \\
\hline PH & $\begin{array}{l}99.19 \\
\pm 2.50\end{array}$ & 79.50 & 119.25 & 56.00 & 61.72 & 7.54 & 7.92 & 90.74 & 14.71 & 14.83 \\
\hline GFP & $\begin{array}{l}67.04 \\
\pm 1.64\end{array}$ & 57.75 & 78.25 & 15.08 & 17.70 & 5.79 & 6.27 & 85.21 & 7.39 & 11.03 \\
\hline TKW & $\begin{array}{l}36.06 \\
\pm 1.60\end{array}$ & 26.02 & 44.80 & 6.45 & 11.70 & 7.04 & 9.48 & 55.11 & 3.89 & 10.78 \\
\hline HLW & $\begin{array}{l}76.18 \\
\pm 0.73\end{array}$ & 72.31 & 80.26 & 1.79 & 3.18 & 1.76 & 2.34 & 56.38 & 2.07 & 2.72 \\
\hline BMY & $\begin{array}{l}7543.3 \\
\pm 617.78\end{array}$ & 5641.2 & 9588.3 & 285428.10 & 550566.95 & 7.08 & 9.84 & 51.84 & 793.58 & 10.52 \\
\hline HI & $\begin{array}{l}45.66 \\
\pm 4.89\end{array}$ & 24.86 & 60.94 & 21.78 & 46.63 & 10.22 & 14.96 & 46.69 & 6.58 & 14.41 \\
\hline SL & $\begin{array}{l}8.11 \\
\pm 0.48\end{array}$ & 6.70 & 10.30 & 0.37 & 0.47 & 7.47 & 8.48 & 77.78 & 1.10 & 13.60 \\
\hline NSS & $\begin{array}{l}19.41 \\
\pm 0.90\end{array}$ & 17.00 & 23.00 & 0.98 & 1.51 & 5.11 & 6.32 & 65.28 & 1.65 & 8.51 \\
\hline NGS & $\begin{array}{l}51.81 \\
\pm 2.74\end{array}$ & 43.75 & 64.25 & 4.21 & 14.21 & 3.96 & 7.27 & 29.62 & 2.30 & 4.45 \\
\hline GIY & $\begin{array}{l}3534.33 \\
\pm 286.38\end{array}$ & 2245.10 & 4591.60 & 14746.05 & 237550.54 & 3.44 & 13.79 & 6.21 & 62.42 & 1.77 \\
\hline
\end{tabular}

Where: $\delta^{2} \mathrm{p}=$ Phenotypic variance, $\delta^{2} \mathrm{~g}=$ Genotypic variance, $\delta^{2} \mathrm{~g} \mathrm{l}=$ variance of genotype by location interaction, $\mathrm{PCV}=$ phenotypic coefficient of variance, $\mathrm{GCV}=$ Genotypic coefficient of variation, $\mathrm{H}^{2}=$ Broad sense heritability, $\mathrm{GA}=$ genetic advance, $\mathrm{GA}(\%)=$ Genetic advance as percent of mean. Abbreviations: $\mathrm{DH}=$ Days to heading, $\mathrm{DM}=$ Days to maturity, $\mathrm{PH}=\mathrm{Plant}$ height, $\mathrm{GFP}=\mathrm{Grain}$ Filling Period, TKW=Thousand Kernels Weight, HLW=Hectoliter weight, BMY=Biomass Yield, HI=Harvest 
Index, SL=Spike Length, NSS=Number of spikelet per spike, NGS=Number of Kernels per Spike, $\mathrm{GlY}=$ Grain yield (Kg/ha).

\section{SuMMARY AND CONCULUSSION}

Genetic variability among the tested varieties from different traits helpful for direct and indirect selection. Attention should be given for traits which has moderate to high variability and genetic advance in order to bring an effective response of grain yield improvement. The variability among the genotypes, heritability and associations in the tested traits of the genotypes confirmed possibility to increase wheat productivity in target area. Hence, selection and hybridization on those genotypes based on the trait with high GCV, heritability, and genetic advance on grain yield can be recommended for further yield improvement of bread wheat at particular location.

\section{ACKNOWLEDGMENT}

I acknowledged Ethiopian Institute of Agricultural Research for the source of budget to conduct this research. Secondly, I would like thanks to the member of wheat improvement staff of Holetta and Kulumsa Agricultural Research Center their help during field data collection. Finally, I would like to thank my brother he gave me the valuable information and recognized for their support during data management and data analysis.

\section{REFERENCES}

[1] Adhiena, M., Wassu, M. and Tadesse, D., 2016. Estimation of heritability and genetic advance of yield and yield related traits in bread wheat (Triticum aestivum L.) genotypes at Ofla District, Northern Ethiopia. International Journal of Plant Breeding and Genetics, 10(1), pp.31-37.

[2] Allard, R.W., 1960. Principles of plant breeding. John Willey and Sons. Inc. New York, 485.

[3] Awale, D. Takele, D. and, Mohammed, Sh. 2013. Genetic variabilityy and traits association in bread wheat (Triticum aestivum L.) genotypes. International Research Journal of Agricultural Sciences, 1(2): 19-29.

[4] Bayisa, T., Tefera, H. and Letta, T., 2020. Genetic variability, heritability and genetic advance among bread wheat genotypes at Southeastern Ethiopia. Agriculture, Forestry and Fisheries, 9(4), p.128.

[5] Bekele H, Verkuiji W, Mawangi T. (2000). Adaptation of improved heat technologies in Addaba and Doddola Worede's of the Bale highlands of Ethiopia. CIMMYT/EARO, Addis Ababa, Ethiopia.

[6] Burton, G.W., and Devane, E.H., 1953. Estimating heritability in tall fesscusce from Replicated clone natural materials. Agronomy Journal, 45: 171-181.

[7] Bezabeh E. (2015). Change and growth rate analysis in area, yield and production of wheat in Ethiopia. Research Journal of Agriculture and Environmental Management. 4(4), 189-191.

[8] Bhushan, B., Gaurav, S.S., Kumar, R., Pal, R., Panday, M., Kumar, A., Bharti, S., Nagar, S.S. and Rahul, V.P., 2013. Genetic variability, heritability and genetic advance in bread wheat (Triticum aestivum L.). Environment and Ecology, 31(2), pp.405-407.

[9] Clarke, F.R., Clarke, J.M., Ames, N.A., Knox, R.E. and Ross, R.J., 2010. Gluten index compared with SDSsedimentation volume for early generation selection for gluten strength in durum wheat. Canadian Journal of Plant Science, 90(1), pp.1-11.

[10] Dabi, A., Mekbib, F. and Desalegn, T., 2019. Genetic variability studies on bread wheat (Triticum aestivum L.) genotypes. Journal of Plant Breeding and Crop Science, 11(2), pp.41-54.

[11] Dargicho, D., Sentayehu, A., Firdisa, E. and Ermias, A., 2015. Genetic variability in bread wheat (Triticum aestivum L.) germplasm for yield and yield component traits. Journal of Biology, Agriculture and Healthcare, 5(17), pp.140-147.

[12] Deshmukh, S.N., Basu, M.S. and Reddy, P.S., 1986. Genetic variability, character association and path coefficients of quantitative traits in Virginia bunch varieties of groundnut. Indian Journal of Agricultural Sciences.

[13] Destaw M, Shiferaw A and Kifle A, 2020. Study of genetic variability in some bread wheat accessions (Triticum aestivum L.) in Gurage zone, Ethiopia. Asian J. Biol. Sci., 13: 309-317.

[14] Falconer, D. S. (1981). Introduction to quantitative genetics. Ed. 2. Longmans Green, London/ New York.

[15] Falconer, D.S., Mackay, T.F. and Frankham, R., 1996. Introduction to quantitative genetics: trends in genetics. Harlow: Longman Frankel, 12 (7), p.280. 
[16] FAOSTAT. (2018). FAOSTAT statistical database Accessed 16 July 2018. www.fao.org/faostat/.

[17] Fassil K, Teklu E, Teklu T, Assefa G. (2000). On-farm demonstration of improved durum wheat varieties under enhanced drainage on vertisols in the Central Highlands of Ethiopia. In: The Eleventh Regional Wheat Workshop for Eastern, Central and Southern Africa (p. 45).

[18] Fikre, G., Alamerew, S. and Tadesse, Z., 2015. Genetic variability studies in bread wheat (Triticum aestivum L.) genotypes at kulumsa agricultural research center, south east Ethiopia.

[19] Ghallab, K. H., Aziz, A., Sharran, N., Shalby, N., 2016. Genetic parameters for yield and yield components traits of some wheat genotypes grown in newly reclaimed soils, 9(4): 1-8.

[20] Gezahegn, F., Sentayehu, A. and Zerihun, T., 2015. Genetic Variability Studies in Bread Wheat (Triticum aestivum L.) Genotypes at Kulumsa Agricultural Research Center, South East Ethiopia. Journal of Biology, Agriculture and Health care, 5(7): 89-98.

[21] Gomez, K., and A. Gomez. 1984. Statistical Procedures for Agricultural Research $2^{\text {nd }}$ ed. A Wiley Inter science Publication. John Wiley and Sons. New York. Chichester. Brisbane. Toronto. Singapore, pp 680.

[22] Hamdi, A., Ghareib, A.A., Shafey, S.A. and Ibrahim, M.A.M., 2003.Genetic variability, heritability and expected genetic advance for earliness and seed yield from selection in lentil. Egyptian Journal of Agricultural Research, 81:125-138.

[23] Hanson CH, Rabinson HE, Comstock RE (1956) Biometrical studies of yield is segregating population of Korean lespedeza. Agron J 48: 268-272.

[24] Hartley, H.O., 1950. The maximum F- Max ratio as a short-cut test for heterogeneity of variance. Biometrical, 37 (3/4): 308-312.

[25] Johnson HW, Robinson HF, Comstock RE (1956) Genotypic and phenotypic correlations and their implication in selection. Agron J 47: 477-483.

[26] Johnson, H.W., Robinson, H.F. and Comstock, R.E., 1955. Estimates of genetic and environmental variability in soybeans 1. Agronomy journal, 47(7), pp.314-318.

[27] Kefale, H. and Menzir, A., 2019. Genetic variation of bread wheat (Triticum aestivum L.) varieties based on phenological, morphological and quality traits at Guay Kebele in Debre Elias District, East Gojjam Zone, Northwestern Ethiopia. Journal of Biology, Agriculture and Healthcare, 9(11), pp.45-55.

[28]Khalil, A., Mahboob, A. Sher, M. and A.J. Pirzada., 2010. Comparative Performance of Wheat Advance Lines for Yield and its Associated Traits. IDOSI Publications.World Applied Sciences.

[29] Letta T. (2013). Association mapping reveals novel stem rust resistance loci in durum wheat at the seedling stage. The Plant Genome: doi: 10.3835/plant genome, 2013. 08.00.

[30] Majumder, D.A.N., Shamsuddin, A.K.M., Kabir, M.A. and Hassan, L. 2008. Genetic variability, correlated response and path analysis of yield and yield contributing traits of spring wheat. Journal of Bangladesh Agricultural University, 6(2): 227-234.

[31] Mecha, B., Alamerew, S., Assefa, A., Dutamo, D. and Assefa, E., 2016. Correlation and path coefficient studies of yield and yield associated traits in bread wheat (Triticum aestivum L.) genotypes. Adv. Plants Agric Res, 6(5), pp.1-10.

[32] Meles, B., Mohammed, W. and Tsehaye, Y., 2017. Genetic variability, correlation and path analysis of yield and grain quality traits in bread wheat (Tritium aestivum L.) genotypes at Axum, Northern Ethiopia. Journal of plant breeding and crop science, 9(10), pp.175-185.

[33] Muhder, N., Gessese, M.K. and Sorsa, Z., 2020. Assessment of genetic variability among agronomic traits and grain protein content of elite bread wheat (Triticum aestivum L.) genotypes in the central highlands of Ethiopia. Asian J. Agric. Res., 14: 1-12.

[34] Navin K, Shailesh M, Vijay K (2014). Studies on heritability and genetic advance estimates in timely sown bread wheat (Triticum aestivum L.). Journal Bioscience Discovery 5(1):64-69.

[35] Negasa, D. and Chauhan, D.K., 2016. Variability, Heritability and Genetic Advances in Wheat (Triticum aestivum L.) Breeding lines grown at Horro Guduru Wollega Zone, Western Ethiopia. International Journal of Advanced Scientific Research and Management, 1(1), pp.24-28.

[36] Obsa, Ch. Wassu, W. and Firdissa, E., 2017. Analysis of Genetic Variability among Bread Wheat (Triticum aestivum L.) Genotypes for Growth, Yield and Yield Components in Bore District, Oromia Regional State. Agriculture, Forestry and Fisheries, 6(6):188 - 199.

[37] Panse VG, Sukhatme PV (1967) Statistical methods for agricultural workers. 2nd edn, ICAR, New Delhi, India.

[38] Raia, P.K., Sarkara, U.K., Islamb, A.S., Rahamana, M.A. and Hasan. M., 2016 .Genetic study and selection in the F4 generation of rice (Oryza.sativa L.). Journal of Bioscience and Agriculture Research, 9 (01):768774.

[39] SAS. 2011. Statistical analysis system, version 9.3 editions. SAS Institute Inc. Cary, NC. 
[40] Sears ER. (1966). Nullisomic tetratomic combinations in wheat. In: R Riley, KR Lewis, eds. Chromosome Manipulation and Plant Genetics. Oliver and Boyd, Edinburgh. pp 29-45.

[41] Shukla, S., Bhargava, A., Chatterjee, A. and Singh, S.P., 2004. Estimates of genetic parameters to determine variability for foliage yield and its different quantitative and qualitative traits in vegetable amaranth (A. tricolor)[India]. Journal of Genetics and Breeding (Italy), 58, 169-176.

[42] Singh, B., 2001. Plant Breeding: Principles and Methods, 6th ed., Kalyani Publishers, New Delhi, India.

[43] Tamene, T. Keneni, G. and Mohammad, H., 2015. Genetic progresses from over three decades of faba bean ('Vicia faba'L.) breeding in Ethiopia. Australian Journal of Crop Science, 9(1), pp.41-48.

[44] Ullah, K., Khan, S.J., Muhammad, M.I.T. and Muhammad, S., 2011. Genotypic and phenotypic variability, heritability and genetic diversity for yield components in bread wheat (Triticum aestivum L.) germplasm. African Journal of Agricultural Research, 6(23), pp.5204-5207.

[45] Wolde T, Eticha F, Alamerew S, Assefa E, Dutamo D, Mecha B. (2016). Trait associations in some durum wheat (Triticum durum L.) accessions among yield and yield related traits at Kulumsa, south eastern Ethiopia. Advances in Crop Science and Technology, 4(4), 234.

[46] Xie Q. (2015). Physiological and genetic determination of yield and yield components in a bread wheat $\times$ spelt mapping population [Doctoral dissertation]. University of Nottingham.

[47] Zecevic, V., Knezevic, D., Micanovic, D., Urosevic, D., Dimitrijevic, B. and Urosevic, V., 2001. Components of variance and heritability of quality parameters in wheat cultivars. Genetika, 13(3), pp.77-84.

[48] Zerga, K., Mekbib, F. and Dessalegn, T., 2016. Estimation of association among growth and yield related traits in bread wheat (Triticum aestivum. L) Genotypes at Gurage Zone, Ethiopia. International Journal of Plant Breeding and Crop Science, 3(2), pp.123-134.

Citation: Endashaw Girma Seyoum and Alemnesh Sisay, (2021). "Estimation of Genetic Variability, Heritability and Genetic Advance in Bread Wheat (Triticum aestivum L.) ", International Journal of Research Studies in Agricultural Sciences (IJRSAS), 7(9), pp. 17-26. DOI: http://dx.doi.org/ 10.20431/24546224.0709004

Copyright: (C) 2021 Authors. This is an open-access article distributed under the terms of the Creative Commons Attribution License, which permits unrestricted use, distribution, and reproduction in any medium, provided the original author and source are credited. 